\title{
IMPACT OF ETHNIC TOURISM ON INTER-ETHNIC RELATIONS
}

\author{
(C) Tatiana V. Vergun, Denis V. Grishin
}

\author{
North Caucasus Social Institute, Stavropol, Russian Federation \\ t-vergun@ya.ru; denis_grishin@mail.ru
}

Issues of impact of ethnic tourism on formation of inter-ethnic relations are considered. It is noted that the growth of ethnic identity can lead to the emergence on the market of tourist products, new proposals that will take into account the growing interest of people in understanding the culture and life both of their ancestors and of representatives of other ethnic groups. The development of issues which are related to the ontogenesis of ethnotourism has arisen relatively recently, researches of this nature are still new. The conceptual questions are also in the formation stage. Most researchers of this topic highlight the main purpose of ethnic tourism as familiarity with the peculiarities of traditional material and spiritual culture, the unique way of life of the ethnic group, traditions and customs. Such a definition of "ethnic tourism" can be considered the most generic and universal. Ethnic tourism as a phenomenon is a significant element in the understanding of interethnic relations and inter-ethnic culture. In practice, this is realized through the promotion of ethnic tourism and awareness of its importance for the tourist industry as a whole. From a theoretical perspective, ethnic tourism is a productive strategy for raising awareness of the concepts of "ethnic identity" and "ethnic relations". As a conclusion, it is noted that the emergence and strengthening of positive trends in the development of ethnotourism are particularly relevant, as they contribute to the preservation of the cultural and historical heritage of an ethnic group, they support the identity of ethnic groups, and they are a factor of the sustainable development of their traditional territories. Considering ethnic identity and tourism, one can say with confidence about interinfluence of these two elements. Tourism, one of the largest industries in the world, has an impact on the formation of the ethnic identity of the person.

Key words: ethnic tourism, cultural tourism, inter-ethnic relations, ethnic identity, traditional culture.

\section{[Т.В. Вергун, Д.В. Гришин Влияние этнического туризма на формирование межэтнических отно- шений]}

Рассматриваются вопросы влияния этнического туризма на фоомирование межэтнических отношений. Отмечается, что рост этнического самосознания может повлечь появление на рынке туристских продуктов, новых предложений, которые будут учитывать растущий интерес людей к постижению культуры и быта как своих предков, так и представителей других этнических групп. Разработка вопросов, которые связаны с онтогенезом этнотуризма, возникла относительно недавно, исследования такого характера пока являются новыми. Понятийный аппарат также находится на стадии фрормирования. Большинство исследователей данной тематики главной целью этнического туризма выделяют знакомство с особенностями традиционной материальной и духовной культуры, самобытного уклада жизни этнической группы, традициями и обычаями. Подобное определение термина «этнический туризм» можно считать наиболее обобщенным и универсальным. Этнический туризм как феномен выступает в роли значимого элемента в понимании межэтнических взаимоотношений, межэтнической культуры. На практике это реализуется посредством популяризации этнического туризма и осознания его значимости для туриндустрии в целом. С позиций теории этнический туризм выступает в роли продуктивной стратегии для более глубокого осознания понятий «этническая самобытность» и «этнические отношения». В качестве вывода в работе отмечается, что появление и укрепление положительных тенденций в развитии этнотуризма особенно актуально, поскольку это способствует сохранению культурноисторического наследия той или иной этнической группы, поддерживает самобытный уклад жизни этнических групп, а также является фрактором устойчивого развития территорий их традиционного проживания. Рассматривая этническую идентичность и туризм, можно с уверенность сказать о взаимовлиянии этих двух элементов. Туризм, являясь одной из крупнейших индустрий в мире, влияет на процесс формирования этнической самобытности человека.

Ключевые слова: этнический туризм, культурный туризм, межэтнические отношения, этническая идентичность, традиционная культура. 
Tatiana V. Vergun - Ph.D. in Philosophy, Associate Professor, North Caucasus Social Institute, Stavropol, Russian Federation.

Denis V. Grishin - Ph.D. in Economics, Associate Professor, North Caucasus Social Institute, Stavropol, Russian Federation.

Вергун Татьяна Викторовна - кандидат фрилософских наук, доцент, Северо-Кавказский социальный институт, г. Ставрополь, Российская Федерация.

Гришин Денис Васильевич - кандидат экономических наук, доцент, Северо-Кавказский социальный институт, г. Ставрополь, Российская Федерация.

The development of ethnic tourism at the present stage is becoming a key area of socio-economic activity of individual countries of the world. In recent years, there has been an increase of interest in ethnic culture in our country. The growth of ethnic identity leads to the emergence of tourist regional products, new proposals on the market. They take into account the increased interest of the population in the knowledge of the culture and life of their ancestors.

The scientific environment has also seen a natural increase in the number of researches on various aspects of ethnic tourism as well as its impact on ethnic relations. The current state and prospects of development of ethnic tourism both in Russia as a whole and in individual regions are considered.

As the development of issues related to the development of ethnic tourism has begun relatively recently, researches in this area are innovative. At present the framework of categories and concepts used by the authors of scientific works is also in the initial stage of formation, it is undergoing changes, and it is being refined and supplemented by various elements.

The clarification of the content of the concept of "ethnic tourism" and the identification of it as an independent type of tourism create conditions for its more detailed study. Two varieties of ethnic tourism are identified. These are superficial and deep. Deep ethnic tourism is linked to the authenticity of resources and knowledge. This criterion is determined by the variety of expectations and needs of tourists as well as by the period of time when the tourist gets acquainted with the ethnic group. In addition, the criterion of authenticity combined with other motives of tourists when choosing a route characterizes how much the tourist is immersed in the knowledge of the ethnic group.

In the domestic and foreign tradition most researchers consider that the main purpose of ethnic tourism is familiarization with the peculiarities of traditional material and spiritual culture, the unique way of life of an ethnic group, rites and customs, other ethnic characteristics of individual indigenous peoples and other ethnic communities. We consider this definition of ethnic tourism to be the most generic and universal, possible for the usage as basical in works devoted to ethnic tourism.

People's interest in the culture of other ethnic groups can be of both cognitive and nostalgic character. Tourists are increasingly attracted to the opportunity to become involved in the way of life of the Aboriginal population. This broadens the outlook, allows you to compare your life with the realities of the lives of other peoples, to dip into the past, to learn new knowledge. All this is connected with the cognitive activity of tourists. The nostalgic character is gained by the tours within which tourists visit the places of residence of the ancestors, distant relatives, relatives and close people.

Such authors as Ch.B. Sunduev, L.V. Hishiktueva, M.B. Birzhakov, B.M. Surtayev refer ethnic tourism to the direction of cultural and cognitive $[8,53$ p.], cultural $[9,178$ p.] or cognitive tourism [2, 22 p.]. Others, such as N.A. Malova, A.V. Babkin, N.E. Moraleva, E.Y. 
Ledovskikh use the concepts of ethnic and ethnographic tourism in their works, without distinguishing them, recognizing them as synonyms [3, 58 p.]. Still others clearly distinguish ethnic tourism and ethnographic tourism. Such authors include A. I. Schukin, who in his study indicates that the first of them is aimed at meeting the spiritual needs of a wide range of consumers, the second is intended rather for scientists-specialists engaged in studying the culture of various ethnicities professionally [10, 15 p.].

While in the domestic tradition there is uncertainty in the ratio of the concepts of "ethnic tourism" and ethnographic tourism, in foreign literature there is an inconsistency between the concepts of ethnic tourism and cultural tourism [7, 181 p.].

Thus, R. Vud and V. Smith consider that ethnotourism and cultural tourism need to be distinguished, but both authors in their works do not clearly define either one or another type of tourism [6, 260 p.]. The Japanese researcher K. Yasumura, on the contrary, by analyzing various approaches to the definition of "ethnic tourism," concludes that ethnotourism cannot be considered as an independent branch, but should be considered as a form of cultural tourism [5].

This kind of inconsistency of the authors' views on ethnic tourism leads to the fact that ethnic tourism as an independent branch has been still taking an insignificant place in tourism flows. However, at the time of reducing of ethnic diversity, and eroding of the identity of individual social groups and peoples in the conditions of increasing globalization, the inclusion of ethnic tourism in a full and independent tourism and its active development is becoming increasingly evident [6, 260 p.].

In the context of world globalization, peoples and their cultural values are also being globalized [12, pp. 3-9]. There are questions of the preservation, revival and spread of the identity of ethnic groups and peoples. The creation of a single tourist communication space absorbs the local identity of individuals and ethnic groups and raises the problem of preserving cultural and linguistic diversity for the sustainable development of States and regions [13, pp. 41-47]. Will the destruction of self-identification of regions that receive tourists become the result of globalization? It depends on the extent to which the region is able to define and resist the framework of its "local identity".

In contrast to the impact of globalization, there is a trend of localization that leads to homogenization of cultures. It aimed to preserve awareness and "sense of identity, home and community" [4, 16 p.]. While trends of globalization blurred boundaries of national and destroyed the characteristics of ethnic cultures, localization trends contributed to the creation and promotion of unique, ethnically rich tourism products on the world market.

When these two trends interact, a new course of "glocalization" has emerged, which combines global and local characteristics in the promotion of tourist products. It means that the local tourist product has to be adapted for understanding and perception in the world tourist market.

Ethnic tourism as a phenomenon acts as a significant element in understanding of inter-ethnic relations, inter-ethnic culture, and awareness in modern civilization of its own ethnic identity. In practice, this is realized through the dissemination of ethnic tourism and awareness of its importance for the tourism industry as a whole. From the perspective of theory, ethnic tourism is a productive strategy for raising awareness of the concepts of "ethnic identity" and "ethnic relations." The basic principles supporting these arguments are:

- First, consideration of tourism as a form of inter-ethnic interaction;

- Secondly, the formation of vectors for the development of ethnic tourism, where ethnic tourism is the defining moment in the formation of ethnic identity; 
- Thirdly, the tourist sphere makes it possible to combine into a whole such concepts as visual aspects and experience, which contribute to the perception of artifacts of ethnic culture $[1$, p. 26].

Ethnic tourism brings together two very different fields, ethnicity, on the one hand, and tourism industry, on the other. In fact, it is impossible, at first glance. However, issues of ethnic identification and inter-ethnic interaction have remained at the peak of popularity for half a century, and there was no need in tourism industry to understand the importance of ethnic tourism in the formation of inter-ethnic interaction. Neither social science nor economic tradition had a comprehensive study of the subject. It was quite often popularized to condemn becoming a commodity by giving tourists a demonstration of artifacts of some particular authentic culture.

In fact, ethnic tourism is important in shaping inter-ethnic relations and formalizing ethnic identity. Promoting the importance of ethnic tourism for the preservation of the cultural heritage of certain ethnic groups of small peoples may be an argument in support of this position.

Some researchers came directly to the study of tourism from the study of inter-ethnic relations [3, 58 p.]. Tourism is often a form of inter-ethnic relations. As a rule, the tourist, the object of his interest, particularly in cultural and ethnic tourism, and the intermediary who brings them together represent three different and economically unequal ethnic groups. Considering tourism infrastructure more broadly, taking into account tour operators, state and municipal bodies engaged in promotion of tourism, it is possible to further expand the range of interaction of ethnic groups involved in tourism [1, $27 \mathrm{p}$.]. This indicates that tourism should be considered as a structural element of the global phenomenon of ethnicity and ethnic stratification, not as anything outside it. Tourism often changes relationships in ethnic groups, attitudes towards the State and other ethnic groups.

Thus, the study of inter-ethnic relations in the context of tourism provides a way of identifying processes both in the reproduction and restructuring of national relations and in the vision how these processes are increasingly connected with different processes of globalization.

Some researchers consider that the world culture exists on the basis of diversity organization [8, 54 p.]. Tourism is a major way of visualizing and structuring diversity as well as its obtaining. It is related, to varying degrees, to different forms of world heritage as well as to the world population migration.

It is considered that the emergence of national diaspora as a result of global migration is one of the key factors affecting modern identity [9,180 p.]. Tourism has contributed to the development of various forms of diaspora by dispersing individuals around the world who often become local entrepreneurs in tourism. They are also, most often, generators of "hybrid cultures" and "new ethnos." The study of tourism highlights the relative resilience of ethnic identity as ethnicity is inherently hereditary.

In order to maintain interest in the preservation of traditional culture, it is necessary to involve the younger generation in the process of bringing ethnic culture to the market by promoting ethnic tours filled with various theatrical performances, music, ethnic food and other attributes of this or that ethnic culture. This will enable the younger generation to generate new sources of income and serve as an additional incentive to preserve the identity of ethnic culture. Unfortunately, those ethnic cultures that fail to monetize the achievements of their people by stimulating tourist interest in themselves are doomed to disappear, they become merely museum exhibits [1, 27 p.].

In order to solve the problems of development of ethnic tourism, it is necessary to strengthen State support for tourism business, strengthen the legislative base of tourism 
and cooperation between State authorities and organizations that are related to ethnic tourism. Ethnic tours attract tourists with certain ethnographic objects and specific nationalities. It follows the need to create new routes and combine existing routes. It is necessary to include ethnic direction not only in regional, but also in federal tourism development programs. All this can contribute to the new level of development of ethnic tourism, which is the only possible way to preserve unique traditional landscapes and traditional cultures. But with the wrong organization, this type of tourism can contribute to the rapid degeneration of peoples and the destruction of existing cultural landscapes.

Thus, the emergence and strengthening of positive trends in this sphere of tourism industry are particularly relevant, as they contribute to the preservation of the cultural and historical heritage of the country, maintenance of the unique way of life of ethnic groups ethnic stratification as well as they are a factor of sustainable development of their traditional territories. The object of tourism, internal and inter-ethnic, can be an important force for restructuring inter-ethnic relations. In considering ethnic identity and tourism, one can say with confidence about interinfluence of these two elements. Tourism, being one of the largest industries in the world, affects the process of the formation of the ethnic identity of the person [11, pp. 3-10].

\section{Лumepamypa}

1. Адаева Д.О. Этнический туризм - вид или разновидность? // Научный фоорум. Сибирь. 2016. Т. 2. № 3. С. 26-27.

2. Бахтина С.М., Смирнов Д.В. Этнический туризм в России на современном этапе развития индустрии туризма // Управление в условиях глобальных мировых трансформаций: экономика, политика, право Сборник научных трудов. Международная конференция. 2018. С. 21-23.

3. Клейман A.A. Туризм как важнейшая отрасль экономики: динамика, проблемы и перспективы развития // Межрегион. науч.-практ. конф. «Туризм - путь достижения Целей Тысячелетия». Ч. І. СПб: Невский фронд, 2008. С. 55-61.

4. Логвина E.B. Развитие этнического туризма в Российской Федерации и республике Крым // Учёные записки Крымского фредерального университета им. В.И. Вернадского. География. Геология. Т. 3 (69). 2017. № 2. С. 14-35.

5. Международный семинар «Диалог культур и цивилизаций: мост между правами человека и нравственными ценностями». ЮНЕСКО, Париж, 13-14 марта 2007 г. URL: http://www.un.int/russia/ new/MainRootrus/docs/off_news/150307/newru4.htm

6. Полякова Н.В., Максимов Д.В. Этнический туризм как форма межнациональных отношений // Теоретические и прикладные аспекты современной науки. 2014. № 5-3. C. 259-261.

7. Святоха Н.Ю., Филимонова И.Ю. Подходы к классификации этнического туризма // Вестник Оренбургского государственного университета. 2014. № 6(167). C.179-183.

8. Сундуев Ч.Б., Хышиктуева Л.В. Этнотуризм как одно из направлений культурнопознавательного туризма // Вестн. Бурят. Гос. Ун-та. 2009. № 4. С.53-56.

9. Суртаев Б.М. Этнографический туризм как способ сохранения и возрождения этнокультурного наследия // Вестник угроведения. 2012. № 1. С. 178-182.

10. Щукин А.И. Предпосылки и фракторы развития этнического туризма на СевероЗападе Российской Федерации: Автореф. дис. ... канд. геогр. наук. СПбГУ, СПб, 2002. 22 c. 
11. Goncharov V., Kolosova O. Ethnocultural aspect of the study of the social sphere as the basis of human life // Научный альманах стран Причерноморья. 2019. № 3 (19). C. 3-10.

12. Berkovskiy V., Tronina $L$. Social and historical aspect of interaction of ethnic culture and personality in the context of public development // Научный альманах стран Причерноморья. 2019. №1 (17). С. 3-9.

13. Kuleshin M., Leonova N., Nemashkalov P. Historical consciousness as a part of national consciousness: to the problem statement of the research // Научный альманах стран Причерноморья. 2019. №1 (17). С. 41-47.

\section{References}

1. Adayeva D.O. Etnicheskii turizm - vid ili raznovidnost? Nauchnyi forum. [Is ethnic tourism a species or a variety? Scientific Forum]. Siberia. 2016. V. 2. No. 3. pp. 26-27 (in Russian).

2. Bakhtina S.M., Smirnov D.V. Etnicheskii turizm v Rossii na sovremennom etape razvitiia industrii turizma. Upravlenie v usloviiakh globalnykh mirovykh transformatsii: ekonomika, politika, pravo Sbornik nauchnykh trudov Mezhdunarodnaia konferentsiia. [Ethnic tourism in Russia at the modern stage of development of tourism industry. Management in the conditions of global world transformations: Economy, Politics, Law. Collection of scientific works. International Conference], 2018. pp. 21-23 (in Russian).

3. Kleiman A.A. Turizm kak vazhneishaia otrasl ekonomiki: dinamika, problemy i perspektivy razvitiia. Mezhregion. Nauch.-prakt.konf. "Turizm - put dostizheniia Tselei Tysiacheletiia". [Tourism as the most important branch of the economy: dynamics, problems and development prospects. Interregional Scientific Practice Conference "Tourism is a way to achieve the Millennium Goals."] Ch. I. Saint Petersburg: Nevsky Foundation, 2008. pp. 55-61 (in Russian).

4. Logvina E.V. Razvitie etnicheskogo turizma v Rossiiskoi Federatsii i respublike Krym. Uchenye zapiski Krymskogo federalnogo univer-siteta imeni V. I. Vernadskogo. Geografiia. Geologiia. [Development of ethnic tourism in the Russian Federation and Republic of Crimea. Academic notes of the Crimean Federal University named after V. I. Vernadsky. Geography. Geology.]. V. 3 (69). 2017. No. 2. pp. 14-35 (in Russian).

5. Mezhdunarodnyi seminar "Dialog kultur i tsivilizatsii: most mezhdu pravami cheloveka i nravstvennymi tsennostiami". [International Seminar "Dialogue of Cultures and Civilizations: The Bridge between Human Rights and Moral Values".] UNESCO, Paris, March 13-14, 2007. Available at: http://www.un.int/russia/ new/MainRootrus/docs/off _ news/150307/newru4.htm

6. Polyakova N.V., Maksimov D.V. Etnicheskii turizm kak forma mezhnatsionalnykh otnoshenii. Teoreticheskie i prikladnye aspekty sovremennoi nauki. [Ethnic tourism as a form of inter-ethnic relations. Theoretical and applied aspects of modern science]. 2014. No. 5-3. pp. 259-261 (in Russian).

7. Svyatoha N.Yu., Filimonova I.Yu. Podkhody k klassifikatsii etnicheskogo turizma. Vestnik Orenburgskogo gosudarstvennogo universiteta. [Approaches to the classification of ethnic tourism. Journal of Orenburg State University]. 2014. No. 6(167). pp. 179-183 (in Russian).

8. Sunduev Ch.B., Khyshiktueva L.V. Etnoturizm kak odno iz napravlenii kulturnopoznavatelnogo turizma. Vestn. Buriat. Gos. Un-ta. [Ethnotourism as one of the directions of cultural and cognitive tourism. Bulletin of the Burat State University]. 2009. No. 4. pp. 53-56 (in Russian). 
9. Surtayev B.M. Etnograficheskii turizm kak sposob sokhraneniia i vozrozhdeniia etnokulturnogo naslediia. Vestnik ugrovedeniia. [Ethnographic tourism as a way to preserve and develop ethnocultural heritage. Bulletin of Ugric studies]. 2012. No. 1. pp. 178-182 (in Russian).

10. Schukin A.I. Predposylki i faktory razvitiia etnicheskogo turizma na Severo-Zapade Rossiiskoi Federatsii: Avtoref. dis. ... kand. geogr. nauk. SPbGU. [Prerequisites and factors of development of ethnic tourism in the Northwest of the Russian Federation: Autoriferate...thesis Ph.D. in Geography. Saint Petersburg State University.]. Saint Petersburg, 2002. 22 p. (in Russian).

11. Goncharov V., Kolosova O. Ethnocultural aspect of the study of the social sphere as the basis of human life. Science almanac of Black Sea Region Countries. 2019. No. 3(19). pp. 3-10.

12. Berkovskiy V., Tronina L. Social and historical aspect of interaction of ethnic culture and personality in the context of public development. Science almanac of Black Sea Region Countries. 2019. No. 1(17). pp. 3-9.

13. Kuleshin M., Leonova N., Nemashkalov P. Historical consciousness as a part of national consciousness: to the problem statement of the research. Science almanac of Black Sea Region Countries. 2019. No. 1(17). pp. 41-47. 